\title{
Hygienic Conditions in Butcher Shops at the City of Navirai, Brazil -An Applied Case Study
}

\author{
Fernanda I. G. R. Concenço ${ }^{1}$, Gleice N. N. Silva ${ }^{2}$, Samara E. Concenço ${ }^{3}$ \& Leonardo Nora ${ }^{1}$ \\ ${ }^{1}$ Department of Food Technology, Federal University of Pelotas, Capão do Leão, Brazil \\ ${ }^{2}$ State University of Mato Grosso do Sul, Navirai, Brazil \\ ${ }^{3}$ Federal Institute of Technology of Santa Catarina, Campus Santa Rosa do Sul, Brazil \\ Correspondence: Fernanda I. G. R. Concenço, Department of Food Technology, Federal University of Pelotas, \\ Capão do Leão, Brazil. Tel: 55-53-984-362-292. E-mail: fernanirocha@yahoo.com.br
}

Received: April 22, 2018

Accepted: May 24, $2018 \quad$ Online Published: July 15, 2018

doi:10.5539/jas.v10n8p321

URL: https://doi.org/10.5539/jas.v10n8p321

\begin{abstract}
This study comprises the evaluation of the hygienic-sanitary conditions of butcher shops in the city of Naviraí, state of Mato Grosso do Sul, Brazil. Raw meat and meat products are foods widely consumed by Brazilian citizens, which is also widely exported overseas to several regions, including Europe. Due to its composition, high water content and almost neutral $\mathrm{pH}$, which favors the growth of microorganisms, meat handling requires strict hygienic and sanitary guidelines. The city of Naviraí is located in the Central region of Brazil, where beef cattle and beef and meat products are one of the main activities, both for domestic consumption as well as aiming exports. We surveyed two butcher shops by applying a checklist based on the Resolution RDC 216 of September 15, 2004, issued by the Brazilian Health Ministry. The scores were given from $0 \%$ to $100 \%$ and each surveyed item was classified as Satisfactory; Satisfactory with Restriction; or Unsatisfactory. After that, all nonconformities were pointed out and owners were instructed on how to fix them. Several items for both butcher shops were in disagreement with the cited legislation, being classified as unsatisfactory and satisfactory with restrictions. It was evidenced the need for most intensive inspection by the Sanitary Vigilance Department of the Brazilian Health Ministry, not only by applying fines and other penalties, but also with guidelines to employees and owners, since the lack of information, awareness and commitment is notorious.
\end{abstract}

Keywords: hygienic-sanitary conditions; butcher shops; best management practices

\section{Introduction}

Meat is undoubtedly one of the most consumed foods by Brazilian citizens, with red (bovine and pork) or white (poultry and fish) meat being present in the diet of the majority of the population, independent of the age group. Assunção et al. (2012) studied the consumption of meat by teenagers in the Southern Brazil and found that $43 \%$ of this group consume red meat and $28.3 \%$ white meat and its derivatives, on a daily basis. Between 2006 and 2007, the average number of children over 6 months of age who consume red meat daily in Brazil is $24.6 \%$, but the Center-West region has a percentage above the national average, with $34.9 \%$ (Bortolini, Gubert, \& Santos, 2012).

In a study carried out about the frequency of consumption of white meat and its derivatives, Faria, Ferreira and Garcia (2005) found that $28.4 \%$ of the population of Belo Horizonte, Brazil, consume it once a week; $26.2 \%$ consumes it two to three times a week; and $7.0 \%$ consumes it daily. The other interviewed citizens reported consuming white meat and its derivatives biweekly or once a month.

The city of Naviraí is located in the southern region of the Brazilian state of Mato Grosso do Sul, being a great beef producer, involving processes from cattle raising to slaughtering, processing and marketing. Three major beef slaughterhouses (two submitted to the Federal Inspection Service [SIF]; one to the State Inspection Service [SIE]), supply the local and national demand, and the exceeding production is exported to the international market, whose destinations include the European Union.

According to the Municipal Sanitary Service (SIM), the city's internal commerce has 18 butcher shops, of which 6 are located into supermarkets, to meet local consumption demand. The products marketed in these establishments come not only from the internal production of the city, but also from other neighboring cities. 
These butcher shops must follow the Best Management Practices guidelines, as they are food market establishments. Meat and its derivatives are highly perishable products, due to its chemical composition, high water content and water activity, and $\mathrm{pH}$ near neutrality, which favors the growth of microorganisms. Also, its origin, conditions of processing, storage and transport are key factors to guarantee its quality for both domestic and international markets (Jay, 2005).

Therefore, we aimed with the present study to evaluate the hygienic and sanitary conditions of the facilities, employees, and operational processes during the reception, processing, storage and exposure stages of meat and meat-derived products in two model establishments that commercialize these products at the city of Naviraí-MS, Brazil, aiming to help to understand the nature and deepness of the problems surrounding the meat market in that Brazilian region.

\section{Method}

The present work constitutes a Case Study and was developed based on data collected during field research involving two major butcher shops in the city of Naviraí, state of Mato Grosso do Sul, Brazil. For the evaluation of the hygienic-sanitary conditions of the establishments, a checklist was previously prepared based on the items considered by the Resolution RDC 216, effective since September 15, 2004, issued by the Brazilian Ministry of Health (Brasil, Ministério da Saúde, 2004). Oliveira, Brugnera, Mendonça, and Piccoli (2008a) used a checklist based on Best Management Practices in accordance to the cited Resolution, with consistent results which supported the further decision-making procedure in solving the identified problems. Thus, we decided to adopt a similar methodology for our study.

The checklist was organized in subsections, into which several items based on the Resolution were grouped. The exception was the exclusion of the items at RDC 216 related to "food preparation for direct consumption" since they do not apply to the present study. It should be mentioned that the Brazilian Regulations related to food production and management are more stringent than laws from several other Countries, including several of those which are international destinations for beef produced at the studied Brazilian region. Thus, several points considered nonconformities in the present study may still be in compliance with Regulation Terms in other Countries.

A trained evaluator, Bachelor in Food Technology, accompanied by a Food Technician employed at each of the butcher shops (coded "A" and "B" for the present study), surveyed the two butcher shops. During the survey, all nonconformities were annotated according to the checklist. Data were plotted in tables and the percentages of achievement (PA) were calculated. The establishments were thus classified as Unsatisfactory (PA $\leq 50 \%$ ); Satisfactory with Restrictions $(50 \%<\mathrm{PA}<70 \%$ ), and Satisfactory (PA $\leq 70 \%$ ); as proposed by Soto et al. (2009). All data was processed into the statistical environment " $R$ " (R Core Team, 2017).

\section{Results and Discussion}

All data collected in the model butcher shops is summarized, by theme, at Table 1, where the main recommendations for improvement are also summarized. The problems identified at such butcher shops represent, in general terms, most of the problems faced in the others 16 butcher shops located at the same city; thus, being used as reference.

\subsection{Facility Infrastructure}

In the butcher shops "A" and "B", the percentage compliance scores were $70.7 \%$ and $65.9 \%$, respectively. In the first shop, the nonconformities involve structural faults considered light, such as peeling paint, cracks in doors, loose electricity sockets, etc. In the second establishment, faults included employees counter-flow in the food storage areas as well as in the employee entrance doors; side-by-side to the bathrooms doors, and locker rooms with infra-structure problems; there were no lockers for personal belongings and they were located too near the production area, which could collaborate to food cross-contamination.

In both butcher shops, it was evidenced food consumption by employees near the preparation and storage areas, which is not allowed by RDC 216 in any environment of trade and food handling. The environment must be well ventilated, but the airflow should not be directed to the meat, nor collaborate to any type of contamination. In both shops it was verified that ventilators were poorly positioned, sometimes directly pointing to the table where the raw meat was being handled.

At the butcher shop "B", the structural thermometers used to measure both the freezer chamber and the handling room temperatures were not working properly. Valente and Passos (2004) reported that structural problems in bathrooms and locker rooms may compromise employee hygiene, thus contributing for meat contamination, 
while Akutsu, Botelho, Camargo, Savio, and Araújo (2005) reported that poor building conditions and faulty control equipment may result in quality loss of meat and its derived products.

Table 1. Proposals for adjustments and improvement in infra-structure, by butcher shop. Navirai-MS, Brazil, 2018

\begin{tabular}{|c|c|}
\hline Butcher Shop "A" & Butcher Shop "B" \\
\hline \multicolumn{2}{|l|}{ 1. Adjustments and improvement in infra-structure } \\
\hline \multirow[t]{3}{*}{ Satisfactory; only small recommendations were made. } & $\begin{array}{l}\text { There is need for a new project for structural modifications into the facility. The } \\
\text { counter-flow of employees should be eliminated; the bathrooms should be far from } \\
\text { the meat handling area; personal lockers for the employees should be installed. }\end{array}$ \\
\hline & Ventilator position and directions should be reviewed and corrected. \\
\hline & $\begin{array}{l}\text { The thermometers should be immediately replaced with new ones, in both freezer } \\
\text { chambers and handling rooms. }\end{array}$ \\
\hline
\end{tabular}

\section{Adjustments and improvement in cleaning and sanitation of facilities, equipment and handling tools}

To designate and train some employees to be responsible for To adopt hygienization and sanitation procedure following the Standard Operating sanitation tasks, not allowing them to manipulate meat and its Procedures (PPHOs).

related products.

To use hygiene and sanitation products, registered at the Ministry of Health for use in food processing facilities, according to manufacturer instructions.

To define and deliver training for employees involved in the hygienization and sanitation, preventing them of manipulating meat and its related products.

To use hygiene and sanitation products, registered at the Ministry of Health for use in food processing facilities, according to manufacturer instructions.

3. Adjustments and improvement in the control of pests and its urban vectors

To repair and repaint damaged walls, to repair broken light Satisfactory switches, electrical outlets and plugs.

To install accessories (protective screens in the doors and windows and syphons in drains and sewer outlets) to prevent the access of pests inside the processing area.

4. Adjustments and improvement in water quality and supply

It is proposed to use water from the public supply service, which is properly treated; alternatively, the water quality of

Water reservoirs should be sanitized every six months, according to the RDC 216. the private well should be treated and tested periodically.

Water reservoirs should be sanitized every six months, according to the RDC 216 .

5. Adjustments and improvement in waste disposal practices

To exchange the trash cans for foot operated models

6. Adjustments and improvement in food handling (employees)

Satisfactory Item. However, posters with guidelines for proper hand washing and for others relevant and recurrent procedures are recommended.

Satisfactory item

As a first and urgent step, there is the need for periodical health evaluation for all employees.

Employee training in Best Management Practices, including those to improve hygiene and sanitation standard.

Employees should be warned (and inspected) to not consume foods in the meat handling areas.

To establish sanitary and safety rules for external visitors, which includes the obligation to wear uniform, cap and masks during the visit, and to keep a safe distance from the food handling tables and equipments.

To install posters with guidelines for proper hand washing and for others relevant and recurrent.

7. Adjustments and improvements of handling and storage of raw material, ingredients and packaging

Satisfactory

To fix or replace the thermometers of the storage chambers and register the temperature history in simple spreadsheets.

To establish criteria and evaluate the suppliers of all material utilized, especially the meat suppliers.

To define procedures for storage into the freezing chambers, by storing all material on pallets; never putting boxes directly on the ground.

8. Adjustments and improvement in storage and transportation of food products

The foods should not be stored with no protection; thus, Satisfactory procedures regarding storage should be defined and employees trained.

To register the temperature of the storage chambers in spreadsheets in order to have its history.

9. Adjustments and improvement in documentation and records Satisfactory

To prepare the Best Management Practices manual, as well as the Standard Operating Procedures manual, including all points raised into the present study. If the owner do not have trained personnel for this task, a consultant should be hired. 


\subsection{Cleaning and Sanitation of Facilities, Equipment and Handling Tools}

In this item, the irregularities were basically the same, but only butcher shop "A" had the Standard Operating Procedures (PPHOs) described, but these documents were in need of revision as they were more than two years old. The RDC 216 defines that any establishment that produces and/or markets food derivatives must have its sanitation procedures defined, printed and at hand, but on the other side it does not define expiration dates for these documents. The Sanitary Surveillance Service recommends that at least every 2 years they should be updated; this is not mandatory, but it was considered as nonconformity in the present study. Grades obtained were $56.4 \%$ for butcher shop "A", and $48.7 \%$ for "B".

Both shops did not use chemical products duly registered in competent organs for the hygiene of equipment and utensils used for food processing. They used similar, probably cheaper, products. In addition, the dilution of the product and period of contact with the equipments and utensils were not established. There were no specific employees trained for this task and cleaning was in charge of the same employees who handled the meat, being executed at the end of the labor, or during the activities when needed. Employees did not have basic hygiene training and butcher shop "B" did not have a specific locked room, with restricted access, for storage of the products used for hygiene and sanitation. Non-routine sanitation procedures were not recorded in spreadsheets or notebooks.

Pereira et al. (2002) observed the need for improvement in antisepsis procedures, cleaning and hygiene of materials, recommending the use of duly registered chemicals for that purpose. In addition, the hygiene of walls, floors, ceiling, equipment and utensils is fundamental as it avoids contamination by microorganisms and possible cross contamination (Nunes, L. S. Santos, K. E. C. Santos, Amaral, \& Abreu, 2010).

\subsection{Integrated Control of Pest and Its Vectors}

The scores attributed to the butcher shops for this feature were $66.7 \%$ for shop " $A$ ", and $73.3 \%$ for shop "B". In the butcher shop "A", rat feces were found in the locker rooms. Scratched holes in the door that gives access to the external side served as easy entry for rats. The RDC 216 defines that the structures must be constructed in such a way as to prevent the entry of any kind of pest into the facility. In the butcher shop "B", no structural failures were observed, but there were no pre- and post-treatment procedures for the chemical control of pests in order to avoid food contamination by its residues. In addition, the frequency of pest control at this shop is twice a year, as required by the Health Surveillance Service.

\subsection{Water Supply}

Both butcher shops obtained low scores for this feature ("A" $=37.5 \%$; "B" $=53.8 \%$ ). Among the observed nonconformities, the most noteworthy was that of shop "A", where a private well, without the proper monitoring and treatment, was the only source of water. In addition, none of the establishments clean the water reservoirs every six months, as determined by RDC 216. Valente and Passos (2004) classified as high-risk deficiencies the lack of sanitation of water reservoirs in supermarkets, since this water is used to clean hands and surfaces that come into contact with food.

\subsection{Waste Disposal}

In this item, the scores were $66.7 \%$ for butcher shop " $\mathrm{A}$ " and $83.3 \%$ for butcher shop "B". It was observed that trash cans are not adequate since they have lids with no pedal for opening. According to RDC 216, containers which store garbage should be easily accessed, easy to clean and to transport, specifically equipped with lids without the need for hand operation.

\subsection{Food Manipulator Employees}

Regarding features of those employees directly related to meat manipulation, the scores obtained were $85.7 \%$ for butcher shop "A", and 46.4\% for shop "B". Butcher shop "A" had periodical records about health issues of food manipulator employees, and also trained them in Best Management Practices (BMP). Employees consistently followed hygienic practices as taking proper care of the uniform clothing and the personal hygiene. Butcher shop "B" had no employee health control or records, and they were not trained in hygiene and Best Management Practices as required by RDC 216. Eventually, personnel not wearing uniform and/or cap accessed the production area, and the facility had no rules for external visitors. According to Oliveira, Rolim, Moura, and Mota (2008b), 30.7\% of food manipulators working in butcher shops in the city of Belém, Brazil, have never participated in any kind of training about Best Management Practices, being a similar situation reported by Valente and Passos (2004) for food handlers in supermarkets. 
It is essential that market food establishments invest in employees training, since Oliveira, Silva, Maciel, and Aquino (2008c) report that food manipulators represent one of the main vehicles of meat contamination, since this may be responsible for approximately $26 \%$ of the consumer intoxication cases due to food contamination. None of the establishments had posters to guide about the correct hand hygiene and related recurrent practices, and there was no defined periodicity for uniforms washing. The same authors report that $67 \%$ of the food establishments in João Pessoa (Brazil), among the visited ones, did not have a hand hygiene system according to the legislation.

\subsection{Raw Material, Ingredients and Packaging}

The butcher shop "A" scored $82.5 \%$. Despite having thermometers in the refrigerated storage chambers, there are no records of temperature monitoring for refrigerated and frozen products, both in the reception and storage area. Butcher shop "B" scored 57.5\%. In addition to the nonconformities mentioned above, the storage chamber thermometers were not working. Some plastic boxes containing meat products were placed directly on the floor of the freezing room while they were supposed to be placed on pallets. In addition, there were no criteria for the evaluation of the meat, ingredients and packaging suppliers as described in the RDC 216.

\subsection{Storage and Transportation}

Butcher shop "A" scored $58.3 \%$, as some products were observed into the storage chamber with no packaging. Shop "B" scored $75.0 \%$, but it was found that the thermometer of the storage chambers was not functioning, as mentioned previously, and neither of the shops measure the product temperature. Pereira et al. (2002) observed a similar situation in other butcher shops, proving that this may be a recurring situation. In addition, Oliveira et al. (2008b) found that the meat temperature was higher than the allowed by law in $57 \%$ of the butcher shops surveyed, and $73 \%$ of them did not have air-conditioned rooms for meat manipulation. At the present study, butcher shop "A" has a manipulating room equipped with a domestic air conditioner, which is not sufficient, and butcher shop "B" performs all manipulation in rooms without refrigeration at all.

Temperature control is a crucial point to meet regulatory standards according to the Brazilian laws, because the chemical and physical composition of the meat contribute to microorganism development, being rich in nitrogenous substances, minerals and vitamins. Furthermore, the mean $\mathrm{pH}$ level, water activity and temperature are favorable for microbial growth during meat manipulation. These characteristics contribute to the fact that meat is one of the most susceptible foods in cases of food-borne diseases, since it is not possible to verify food contamination simply by its odor and taste (Baasch, Hasse, \& Alexandrini, 2009).

\subsection{Documentation and Records}

As for the documentation and records, only butcher shop "A" had both the Best Management Practices and the Standard Operating Procedures described, but none of them used spreadsheets to control the process. The butcher shop "A" scored 70\% while "B" scored $0 \%$. Akutsu et al. (2005) verified that several food and nutrition establishments did not have a manual for Best Management Practices, which is considered essential to guarantee food safety.

\subsection{Availability for Consumers in the Shelf}

In general, both butcher shops scored high in this feature. The exposure for sale and consumption is the way the butcher shop shows itself to consumers; thus, this is the part where employees and owners usually give more attention to the whole process. The scores were $81.5 \%$ for butcher shop "A", and $92.6 \%$ for "B"; the nonconformity found was the lack of temperature control.

\subsection{Establishment Classification}

As shown in the previous topics, several nonconformities were found in the visited establishments. In Table 2 it is summarized the classification of establishments as Unsatisfactory, Satisfactory with restrictions or Satisfactory. 
Table 2. Final classification of the butcher shops used in the case study. Navirai-MS, Brazil, 2018

\begin{tabular}{lll}
\hline \multirow{2}{*}{ Item Evaluated } & & Butcher Shop \\
\cline { 2 - 3 } & A & B \\
\hline Facility Infrastructure & $\mathrm{S}$ & $\mathrm{SR}$ \\
Cleaning and sanitation of facilities, equipment and handling tools & $\mathrm{SR}$ & $\mathrm{U}$ \\
Integrated Control of Pest and its Vectors & $\mathrm{SR}$ & $\mathrm{S}$ \\
Water Supply & $\mathrm{U}$ & $\mathrm{SR}$ \\
Sewage disposal & $\mathrm{SR}$ & $\mathrm{S}$ \\
Food Manipulator Employees & $\mathrm{S}$ & $\mathrm{U}$ \\
Raw Material, Ingredients and Packaging & $\mathrm{S}$ & $\mathrm{SR}$ \\
Storage and transportation & $\mathrm{SR}$ & $\mathrm{S}$ \\
Availability for consumers in the shelf & $\mathrm{S}$ & $\mathrm{S}$ \\
Documentation and records & $\mathrm{S}$ & $\mathrm{U}$ \\
\hline
\end{tabular}

Note. U: Unsatisfactory; SR: Satisfactory with restrictions; S: Satisfactory.

As seen in Table 2, most of the items for both butcher shops were not in compliance with the sanitary resolution terms, with a total of $60 \%$ classified as unsatisfactory or satisfactory with restrictions. It becomes clear the need for greater supervision by inspection agencies, not only by applying fines and other penalties, but also in the orientation of owners to follow the law regarding sanitary care with the infrastructure and manipulation of meat products.

The implementation of specific inspection bodies under the Brazilian Ministry of Agriculture, Livestock and Supply (MAPA) in the main meat-producing or meat-processing municipalities, as represented by the city of Naviraí-MS, Brazil, is highly advised.

Another factor that needs to be changed, either by conscientiousness or by enforcement, is the owners commitment and awareness regarding the application of the Best Management Practices guidelines, from the adequacy of the physical structure to the investment in food manipulators qualification.

These procedures will make Brazilian meat processing establishments more competitive and highly conceptualized for both domestic and overseas customers, while ensuring higher product safety and consumer health.

\section{References}

Akutsu, R. C., Botelho, R. A., Camargo, E. B., Savio, K. E. O., \& Araujo, W. C. (2005). Adequação das boas práticas de fabricação em serviços de alimentação. Nutrição, 18(3), 419-427. https://doi.org/10.1590/ S1415-52732005000300013

Assunção, M. C. F., Dumith, S. C., Menezes, A. M. B., Araujo, C. L., Schneider, B. C., Vianna, C. A., ... Madruga, S. W. (2012). Consumo de carne por adolescentes do Sul do Brasil. Nutrição, 25(4), 463-472. https://doi.org/10.1590/S1415-52732012000400004

Baasch, C. A., Hasse, C. R., \& Alexandrini, F. (2009). Monitorização do controle de temperaturas de frigorifico conforme circular 175 do MAPA. Simpósio de Excelência em Gestão e Tecnologia (SEGeT). Retrieved from https://www.aedb.br/seget/arquivos/artigos09/151_frigorifico.pdf

Bortolini, G. A., Gubert, M. B., \& Santos, L. M. P. (2012). Consumo alimentar entre crianças brasileiras com idade de 6 a 59 meses. Cadernos de Saúde Pública, 28(9), 1759-1771. https://doi.org/10.1590/ S0102-311X2012000900014

Brasil, Ministério da Saúde. (2004). Resolução RDC $n^{\circ} 216$ de 15 de setembro de 2004. Dispõe sobre o Regulamento Técnico de Boas Práticas para o Serviço de Alimentação, Diretoria Colegiada da Agência Nacional de Vigilância Sanitária, Brasília.

Faria, I. G., Ferreira, J. M., \& Garcia, S. K. (2006). Mercado consumidor de carne suína e derivados em Belo Horizonte. Arquivo Brasileiro de Medicina Veterinária e Zootecnia, 58(2), 251-256. https://doi.org/10.1590/ S0102-09352006000200014

Jay, J. M. (2005). Microbiologia dos Alimentos (6th ed.). Porto Alegre: Artimed. 
Nunes, L. F., Santos, L. S., Santos, K. E. C., Amaral, D., \& Abreu, I. L. (2010). Condições higiênico-sanitárias dos açougues que comercializam carnes vermelhas no município de Barreiras-BA. Proceedings of the Jornada Cientifica e Tecnológica do Oeste Baiano, 3.

Oliveira, M. M. M., Brugnera, D. F., Mendonça, A. T., \& Piccoli, R. H. (2008a). Condições higiênico-sanitárias de máquinas de moer carne, mãos de manipuladores e qualidade microbiológica da carne moída. Ciência Agrotecnologia, 32(6), 1893-1898. https://doi.org/10.1590/S1413-70542008000600031

Oliveira, R. B. A., Rolim, M. B. Q., Moura, A. P. B. L., \& Mota, R. A. (2008b). Avaliação higiênico-sanitária dos boxes que comercializam carnes em dois mercados públicos da cidade do Recife-PE/Brasil. Medicina Veterinária, 2(4), 10-16.

Oliveira, S., Silva, J. A., Maciel, J. F., \& Aquino, J. S. (2008c). Avaliação das condições higiênico-sanitárias de carne bovina comercializada em supermercados de João Pessoa. Alimentação e Nutrição, 19(1), 61-66.

Pereira, M. P. D., Oliveira, C. S., Pereira, I. A., Martins, G. C., Rodrigues, M. C. D., Santos, R. E., ... Souza, M. M. S. (2002). Avaliação qualitativa da microbiota contaminante em açougues no município de Seropédica como indicador de qualidade higiênico-sanitária. Universidade Rural - Ciências da Vida, 22(2), 147-150.

R Core Team. (2017). R: A language and environment for statistical computing. Vienna: R Foundation for Statistical Computing. Retrieved from https://www.R-project.org

Soto, F. R. M., Cazzola, C. P. B., Oliveira, E., Sakaguti, E., Bernardi, F., Lúcio, D., ... Balian, S. C. (2009). Aplicação experimental de um modelo de inspeção sanitária no comércio varejista de alimentos. Ciência e Tecnologia de Alimentos, 29(2), 371-374. https://doi.org/10.1590/S0101-20612009000200021

Valente, D., \& Passos, A. D. C. (2004). Avaliação higiênico-sanitária e físico-estrutural dos supermercados de uma cidade do sudeste do Brasil. Revista Brasileira de Epidemiologia, 7(1), 1-12. https://doi.org/10.1590/ S1415-790X2004000100010

\section{Copyrights}

Copyright for this article is retained by the author (s), with first publication rights granted to the journal.

This is an open-access article distributed under the terms and conditions of the Creative Commons Attribution license (http://creativecommons.org/licenses/by/4.0/). 